\title{
STUDENTS' PERCEPTION OF USING YOUTUBE IN VOCABULARY MASTERY
}

\author{
Ririn Nurjana Mokodompit, Nurmin F. Samola, I. Javier C. Tuerah, \\ English Education Department, Faculty of Language and Arts, \\ Universitas Negeri Manado, Tondano, Indonesia \\ ririn.mokodompit13@gmail.com
}

\begin{abstract}
The purpose of this study is find how students' perceptions of using YouTube in Vocabulary Mastery. YouTube is online Video sharing platform which allows users to upload, view, and share video from all over the world therefore can also as media online learning especially in mastering vocabulary. The researchers use quantitative research and the sample of this research is 37 students in seven semester of English Education Department, Universitas Negeri Manado. Researchers use questionnaire as instrument in collecting the data. Questionnaire is one of research instrument, which aims for collecting data in survey research and also can be thought of as kind of written interview. The type of questionnaire that used in this research is closed-ended questionnaire. It is used like scale questionnaire in data collection and analyzed in statistical descriptive. Optional for the questioner measuring from strongly agrees, agree, neutral, disagree and strongly disagree. The result in this research is found by seeing the responses of students after distributing the questionnaire and collecting the data. As the result mostly students give positive perception using YouTube in vocabulary mastery and even give good impact to their ability especially in class environment.
\end{abstract}

Keywords : Vocabulary, YouTube, Students' Perceptions

\section{INTRODUCTION}

English has become first foreign language that used along the world, as David Crystal (1997) stated that "English is a global Language" it describes that English is not just foreign language but also a language which connect people to the world. That's why government determine English is foreign language that include in the curriculum to be learnt from elementary school to university level as write on Decree of the minister of education and culture No. 060/U/1993 dated $25^{\text {th }}$ February 1993. It aims to introduce English to the students as early as possible. All those facts show that English become important language to be learnt because by learning English people can connect and able to communicate globally.

Along the process in learning English, vocabulary is one of component that should be learnt and also becomes the basic factor, which helps student to improve their English. The fact, although English becomes compulsory subject, Many students get difficulties in English because the lack of vocabulary. Due to the need of student in mastering vocabulary, variety of ways is done to help find solution to this problem. In this modern era, the progress of internet may help student to learn as often as possible since it's easy reach by the student. For academic filed, internet is source of information because it easier to

JELLT (Journal of English Language and Literature Teaching)

Vol. 5 No. 02 November 2020

P.ISSN: 2548-7728 E.ISSN: 2599-0373 
find many information just by typing the information that needed. According to Caroline Ho Mei Lin (1997), the internet is an extensive resource and communication network link other computer networks across the world. It clearly describes that using internet will help us to find many resource from other part of the world so that it's helpful to learnt or get information through internet. This advantage of internet can be used to enrich the vocabulary of student.

Considering the benefit of internet, there is one of site of internet that is popular in this era which provides online video from all over the world called YouTube. YouTube allows users to upload video, shares and watches video by typing the title of video. By one click the video, which consists information, will be showed. It can be accessed by computer or mobile phone so that student may learn from YouTube anywhere and anytime. Sherman (2003) states that video allows us to introduce any aspect of real life into the language learning environment, contextualizing the learning process. In addition, video also provide combination of sounds and picture and text which is great tools to make student improve their vocabulary mastery.

Based on the descriptions above, although English has been introduced since the elementary school but there are many students get difficulties in learning English because the lack of vocabulary. The important role of vocabulary in learning English and also many benefits of using YouTube since it's easy reach by student lead researcher do this research in order to know students' perceptions of using YouTube in vocabulary mastery especially to college student.

\section{Research Question}

By the descriptions on background of the study above that the important role of vocabulary mastery and the modernization of this era that's why YouTube may be one of good way that can be use in vocabulary mastery therefore the researchers formulate research question; What are the students' perceptions of using YouTube video in Vocabulary mastery?

\section{Purpose of the Study}

The purpose of this study is to find out what the students' perceptions of using YouTube video in vocabulary mastery are.

\section{THEORETICAL BASES Perception}

The word "Perception" comes from the latin word perception, percipio meaning gathering or receiving. In the general understanding perception can be understand as someone's ability to see, to hear, to feel, and to present or to understand or became aware of something or someone feel about the environment and social. Perception started from sense of organ, which is the process of acceptance massage or information by human brain. Koentjaningrat (2010) states that perception is the relialization of human brain process and it appears as a view about phenomenon. Those are.involved by many factors such as motivation, needs, feeling, experience,

Based on the definitions expressed by the experts above, it can be concluded that perception is process about how person interprets information from object or environment outside in other that he is able to give respond or aware of that object or environment. This understanding of perception in this study is process of how students in assessing and responding of using YouTube in vocabulary mastery through their sense and ability.

JELLT (Journal of English Language and Literature Teaching)

Vol. 5 No. 02 November 2020

P.ISSN: 2548-7728 E.ISSN: 2599-0373 


\section{YouTube}

YouTube is online video-sharing platform which its site known as www.youtube.com. It's created from 2005 by Chad Hurley, Steve Chen, and jawed karim. According to Terantino (2011), in his research on emerging technologies, YouTube is used for variety of purposes. Some people use it for work or entertainment but for some people it's can be used for learning. YouTube allow users to share video, view, upload, comment, add to play, like, subscribe, etc. that's why it's easy to watch video which upload from people around the world either for fun or for learning.

Another expert, like Berk (2009) claimes that YouTube video are not only able to attract students' attention, but can cater different learning styles namely verbal, visual, musical, and emotional intelligences. Watching video also allowed the brain to react actively to both side of the brain which helps to increase and enhance students' understanding. In order from this study know that using YouTube video able to help student in increasing their vocabulary master since video help student to get easy understanding of each vocab.

\section{Vocabulary}

Vocabulary is as fundamental basic for the success of the language learning process, including English. In some way to gain understanding along the conversation in English or to produce sentence may be difficult because the lack of vocabulary. The are many experts give their statements about vocabulary. Thornbury Scott (2002), Vocabulary is the first and foremost important step in language acquisition. Another statement come from Zimmerman stated that "Vocabulary is central to language and of critical importance to the typical language learner" those statements clearly describe how vocabulary has important role to produce language, and understanding of information in learning learner.

\section{RESEARCH METHODOLOGY}

This research uses Quantitative research. Quantitative research is a type of research which doing by collecting numerical data. it is support by the statement Aliaga and Gunderson (2002) describe quantitative research methods as the explaining of an issue or phenomenon through gathering data in numerical from and analyzing with the aid of mathematical methods; in particular statistics.

\section{Validity}

In order to know how accurate the items that using in this research, researchers distribute the questionnaires to the students outside the sample. Item analysis using excel formula which compare the score of $r_{x y}$ and $r$ table. Getting the conclusion Valid if value of $r_{x y}$ higher than $r$ table.

Referring to the data or result of the analysis found that all items are Valid because all the values of $\mathbf{r}_{\mathbf{x y}}$ are higher than $r$ table therefore it can be concluded that all the items are Valid.

\section{Reliability}

How dependably a test measures which takes of difference person, time and condition is called reliability. It is support by stated from Drost (2011), reliability is "the extent to which measurements are repeatable when different people perform the measurement on different occasion, under different condition, supposedly with alternative instrument which measure the construct $r$ skill'. Finding the conclusion

JELLT (Journal of English Language and Literature Teaching)

Vol. 5 No. 02 November 2020

P.ISSN: 2548-7728 E.ISSN: 2599-0373 
reliability using excel with Cronbach Alpha technique.

$$
r_{a c}=\left(\frac{k}{k-1}\right)\left(1-\frac{\sum \sigma b^{2}}{\sigma t^{2}}\right)
$$

Where:

$\boldsymbol{r}_{\boldsymbol{a c}}$ refers to Cronbach alpha coefficient reliability

$k \quad$ refers to the number of scale items

$\sum \sigma b^{2}$ refers to the total number of variants per item or each item

$\sigma t^{2}$ refers to total number of variants of all items

After calculating the data, the result found below:

$$
r_{a c}=\left(\frac{10}{10-1}\right)\left(1-\frac{5.003}{21.494}\right)=1.111
$$

\begin{tabular}{|c|c|}
\hline $\begin{array}{l}\text { Cronba } \\
\text { ch's Alpha } \\
\text { Score }\end{array}$ & $\begin{array}{l}\text { Level } \\
\text { of } \\
\text { reliability }\end{array}$ \\
\hline$<0.6$ & Poor \\
\hline 0.6 to $<$ & $\begin{array}{ll}\text { Mode } \\
\text { rate }\end{array}$ \\
\hline $\begin{array}{ll} & 0.7 \text { to }< \\
\end{array}$ & Good \\
\hline $0.9 \quad 0.8$ to $<$ & good \\
\hline 0.9 & lent Excel \\
\hline
\end{tabular}

$\mathrm{x} 0.767=\mathbf{0 . 8 5 2}$

Based on criteria above, it's clearly concluded that 0.852 refers to level of reliability "Very Good".

\section{Data Collection}

Researchers will use questionnaire as instrument in collecting data. Questionnaire is one of research instrument which aims for collecting data in survey research and also can be thought of as kind of written interview. The type of questionnaire that used in this research is JELLT (Journal of English Language and Literature Teaching) Vol. 5 No. 02 November 2020 closed-ended questionnaire. In other that it helps researchers easier to collect information as stated by Fraenkel \& Wallen (2009) that say that a closed-ended statement item is easy to use and score. It is used likert scale, optional for the questioner measuring from strongly agree, agree, neutral, disagree and strongly disagree.

\section{Data Analysis}

The researchers use likert scale questionnaire in data collection and will be analyzed in statistical descriptive. That's why it will be used percentage formula.

$$
\mathrm{V}=\frac{\mathrm{R}}{\mathrm{N}} \times 100 \%
$$

$\mathrm{V}=$ Value of the test

$\mathrm{R}=$ Numbers of respondents' response

$\mathrm{N}=$ Number of the test items

\section{RESEARCH RESULTS AND DISCUSSION}

\section{Result}

After 37 respondents from seven semester students of English Education Department fill out the questionnaires. The results data present in table below.

\begin{tabular}{c|c|c|c|c|c}
\hline Item & SA & A & N & D & SD \\
\hline 1 & 19 & 10 & 5 & 10 & 3 \\
\hline 2 & 21 & 12 & 1 & 0 & 3 \\
\hline 3 & 17 & 12 & 6 & 1 & 1 \\
\hline 4 & 21 & 9 & 5 & 0 & 2 \\
\hline 5 & 13 & 18 & 4 & 0 & 2 \\
\hline 6 & 13 & 20 & 2 & 0 & 2
\end{tabular}




\begin{tabular}{c|c|c|c|c|c}
7 & 21 & 7 & 6 & 2 & 1 \\
\hline 8 & 23 & 9 & 3 & 0 & 2 \\
\hline 9 & 23 & 9 & 3 & 1 & 1 \\
\hline 10 & 17 & 14 & 4 & 1 & 1
\end{tabular}

\section{Data Analysis}

The data show the value data of each item presented in the form of percent. More clearly can be seen in the following table :

\begin{tabular}{c|c|c|c|c|c}
\hline $\begin{array}{c}\text { Ite } \\
\mathrm{m} \\
\text { no. }\end{array}$ & $\mathrm{SA}$ & $\mathrm{A}$ & $\mathrm{N}$ & $\mathrm{D}$ & $\mathrm{SD}$ \\
\hline 1 & $\begin{array}{c}51,3 \\
\%\end{array}$ & $\begin{array}{c}27,0 \\
\%\end{array}$ & $\begin{array}{c}13,6 \\
\%\end{array}$ & $0 \%$ & $\begin{array}{c}8,1 \\
\%\end{array}$ \\
\hline 2 & $\begin{array}{c}56,8 \\
\%\end{array}$ & $\begin{array}{c}32,4 \\
\%\end{array}$ & $\begin{array}{c}2,7 \\
\%\end{array}$ & $0 \%$ & $\begin{array}{c}8,1 \\
\%\end{array}$ \\
\hline 3 & $\begin{array}{c}46,0 \\
\%\end{array}$ & $\begin{array}{c}32,4 \\
\%\end{array}$ & $\begin{array}{c}16,2 \\
\%\end{array}$ & $\begin{array}{c}2,7 \\
\%\end{array}$ & $\begin{array}{c}2,7 \\
\%\end{array}$ \\
\hline 4 & $\begin{array}{c}56,8 \\
\%\end{array}$ & $\begin{array}{c}24,3 \\
\%\end{array}$ & $\begin{array}{c}13,5 \\
\%\end{array}$ & $0 \%$ & $\begin{array}{c}5,4 \\
\%\end{array}$ \\
\hline 5 & $\begin{array}{c}35,1 \\
\%\end{array}$ & $\begin{array}{c}48,6 \\
\%\end{array}$ & $\begin{array}{c}10,9 \\
\%\end{array}$ & $0 \%$ & $\begin{array}{c}5,4 \\
\%\end{array}$ \\
\hline 6 & $\begin{array}{c}35,1 \\
\%\end{array}$ & $\begin{array}{c}54,1 \\
\%\end{array}$ & $\begin{array}{c}5,4 \\
\%\end{array}$ & $0 \%$ & $\begin{array}{c}5,4 \\
\%\end{array}$ \\
\hline 7 & $\begin{array}{c}56,7 \\
\%\end{array}$ & $\begin{array}{c}19,0 \\
\%\end{array}$ & $\begin{array}{c}16,2 \\
\%\end{array}$ & $\begin{array}{c}5,4 \\
\%\end{array}$ & $\begin{array}{c}2,7 \\
\%\end{array}$ \\
\hline 8 & $\begin{array}{c}62,1 \\
\%\end{array}$ & $\begin{array}{c}24,3 \\
\%\end{array}$ & $\begin{array}{c}8,1 \\
\%\end{array}$ & $0 \%$ & $\begin{array}{c}5,5 \\
\%\end{array}$ \\
\hline 9 & $\begin{array}{c}62,1 \\
\%\end{array}$ & $\begin{array}{c}24,4 \\
\%\end{array}$ & $\begin{array}{c}8,1 \\
\%\end{array}$ & $\begin{array}{c}2,7 \\
\%\end{array}$ & $\begin{array}{c}2,7 \\
\%\end{array}$ \\
\hline 10 & $\begin{array}{c}46,0 \\
\%\end{array}$ & $\begin{array}{c}37,8 \\
\%\end{array}$ & $\begin{array}{c}10,8 \\
\%\end{array}$ & $\begin{array}{c}2,7 \\
\%\end{array}$ & $\begin{array}{c}2,7 \\
\%\end{array}$ \\
\end{tabular}

JELLT (Journal of English Language and Literature Teaching)

Vol. 5 No. 02 November 2020

P.ISSN: 2548-7728 E.ISSN: 2599-0373 a. Item 1

\section{Item 1}

\section{$8,1 \%$}
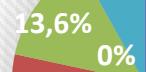

\section{$51,3 \%$}

$27 \%$

- Strongly Agree (SA) $\quad$ Agree (A)

$\square$ Neutral (N) $\quad$ Disagree (D)

- Strongly Disagree (SD)

That result data shown for item or statement number one is the most students strongly agree that YouTube is one of useful tool for learning English vocabulary.

b. Item 2

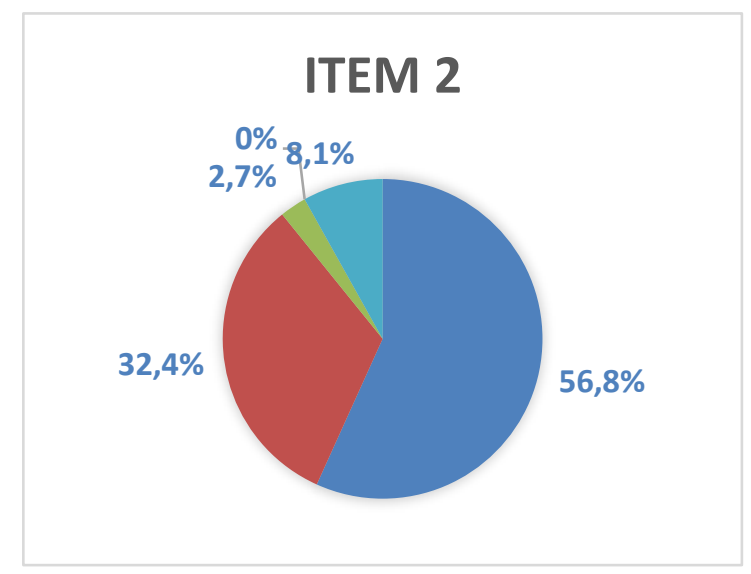

Students mostly state YouTube is easy to reach, easy to understand, and easy to use because all videos able to replay and available to access by phone or computer. 
c. Item 3

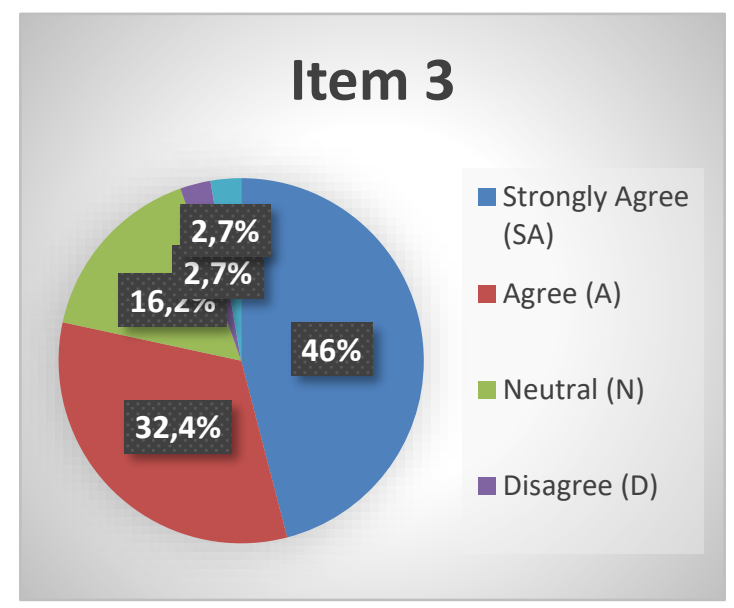

Positive responses about learning English vocabulary by YouTube video is more fun because it's easy to recognize worlds in sentence and also easy to know new word that have not known before.

a. Item 4

\section{ITEM 4}
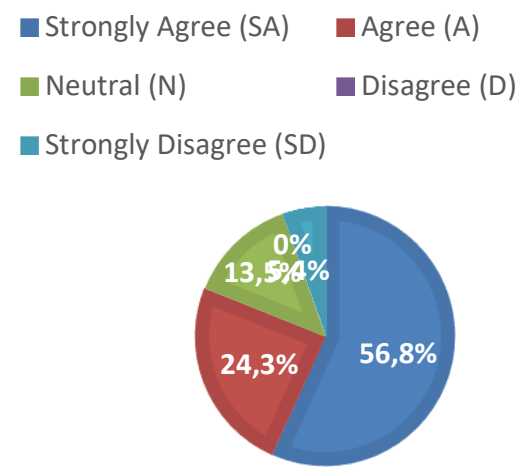

Mostly students state that adding English vocabulary via YouTube is not boring because there are many types of learning videos such as classroom learning videos, song video clips, films, and so on. d. Item 5

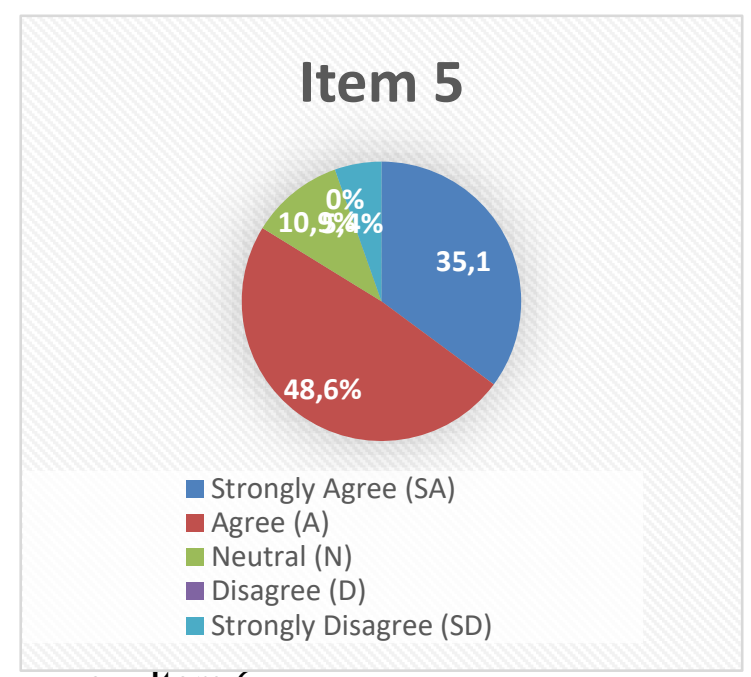

e. Item 6

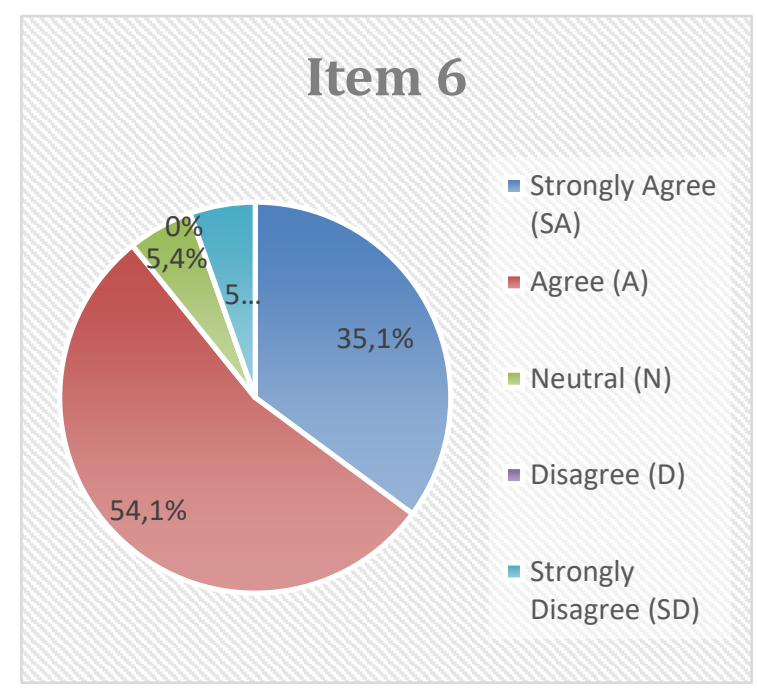

The conclusion that most students agree that learning trough YouTube videos allows them to use the right vocabulary in sentence and helps enrich their vocabulary. 
learning English vocabulary from YouTube video help them to get a better understand of English sentences and enable them to use new vocabulary to make sentence.

f. Item 7

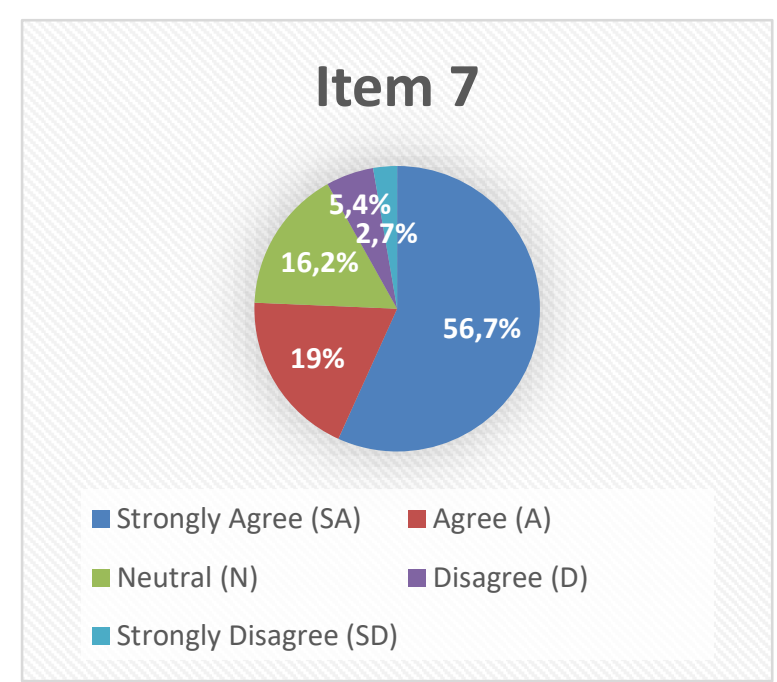

Most students strongly agree if YouTube helps them easily memorize the new English vocabulary that they have learnt.

g. Item 8

\section{CHART TITLE}

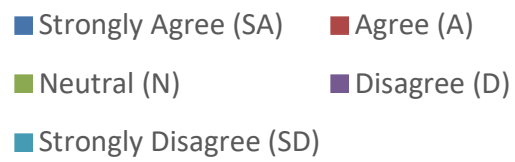

- Strongly Disagree (SD)

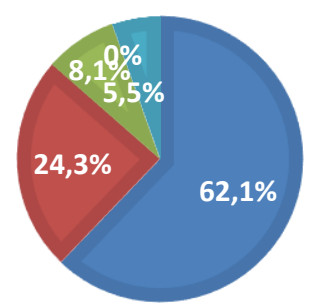

The conclusion is mostly students chose strongly agree that a. Item 9

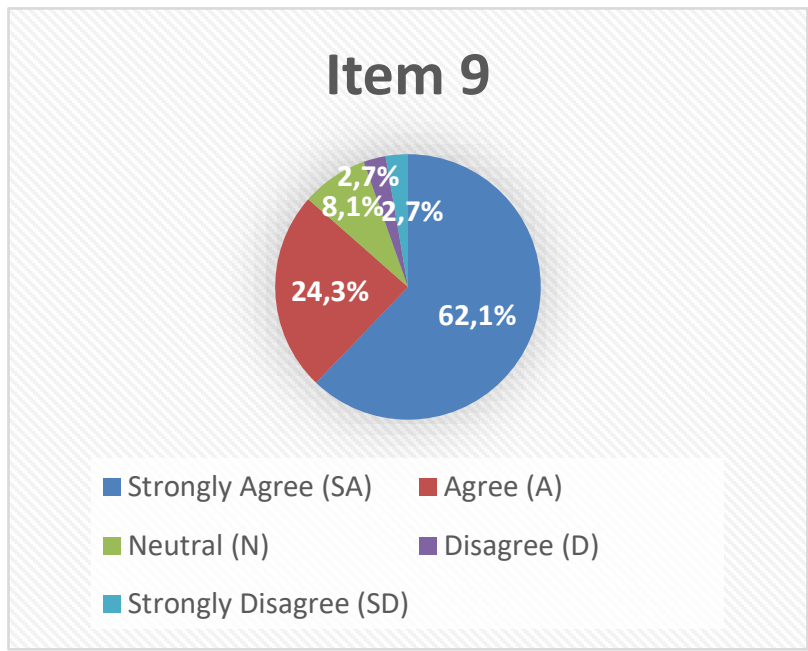

Most students' perceptions strongly agree that learning via YouTube allow them to choose the topic of vocabulary which they want to improve.

h. Item 10

\section{CHART TITLE}
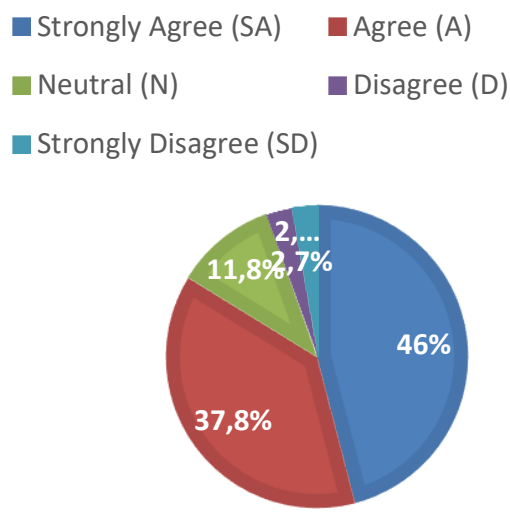
The conclusion get that students mostly give positive responses that learning via YouTube help them improve their English vocabulary so that it has a good impact on the learning process in the classroom.

\section{Discussion}

As shown on the data above that students give most positive perception using YouTube in mastering English vocabulary and also clearly that students' specially seventh semester of English Education Department get good impact even in their class environment by using YouTube to enrich their English vocabulary. The result of the data above, students' show most dominant answers in strongly agree and agree.

\section{CONCLUSION AND SUGGESTION}

\section{Conclusion}

The research discussed how students' perceptions using YouTube in vocabulary mastery. Leading to the analysis result obtained shows that students get good impact using YouTube in vocabulary mastery. The indicators measur in this research are General perceptions of using YouTube in Vocabulary mastery, the effectiveness using YouTube in vocabulary mastery, and the Impact of using YouTube in Vocabulary Mastery. Those indicators represent in item 1 until 10. Most students give responses positive with the result dominantly in strongly agree and agree more than $50 \%$ and less than $10 \%$ choose disagree and strongly disagree. Those data clearly show that students use YouTube in order to enrich their vocabulary each day since it's easy to use by phone and also get the positive impact in English learning process even in the class environment.

\section{Suggestion}

Using YouTube in learning English especially in vocabulary mastery is easy to reach by phone but students sometime get difficult if they out of internet connection therefore in the future English education department hopefully will providing students with free internet connection.

There are many types of video learning in YouTube, some of them are not video from professional but there is also video learning, which come from professional teacher that's why teachers' role is needed to guide student the best source for learning especially in mastery English vocabulary.

\section{REFERENCES}

Aly Anwar Amer. (2002) Advanced

Vocabulary Instruction in EFL. The internet

TESL Journal Vol. vIII no 11, $p, 1$.

Berk, R. A. (2009). Multimedia teaching with video clips: TV, movies, YouTube, and $\mathrm{mtvU}$ in the College classroom. International journal of Teaching and learning, 5(1). 1-21.

Budi Setiwan, (2010), Improving

JELLT (Journal of English Language and Literature Teaching)

Vol. 5 No. 02 November 2020

P.ISSN: 2548-7728 E.ISSN: 2599-0373 
The Students' vocabulary

Mastery Through

Direct Instruction, Surakarta:

Universitas Sebelas Maret, page :8.

Canning-Wilson, C. \& Wallace, J. 2000. Practical Aspects of Using Video in the Foreign Language Classroom. (24 October 2013).

Destiny Apuke Oberiri (2017).

Quantitative Research Methods A Synopsis Approach. Department of Mass Communicaion, P. M. B 1167, Jalingo, Nigeria.

Creswell, Jhon W. (2009), Research design: Qualitative, quantitative and mixed

Approach ( $3^{\text {rd }}$ ed). California: Sage.

Goforth, Chelsea (2015).

Using and Interpreting

Cronbach's Alpha.

University

of Virginia Library

Heriyanto, Dwi. (2015). The

Effectiveness of using

Youtube for Vocabalary

Mastery

Ho Mei Lin, Caroline (1997). The

Internet and English

Language Teaching.

National Institute of

Education (Singapore).

Kubai, Edwin (2019). Reliability and
Validity of Research

Instruments. UNICAF

University - Zumbia.

Kurniawati, Dewi (2013). The

Effectiveness of using YouTube

Video in Teaching English

Grammar Viewed From

Students' Attitude.

http:ejournal.radenintan.ic.id/i

ndext.php/ENGEDU

Leedy, P. \& Ormrod, J. (2001).

Practical research: planning and design ( $\left.7^{\text {th }} e d\right)$.

Upper Saddle River, NJ. San Francisco: Jossey-Bass.

McLoad, S. A. (2014).

Questionnaires. Retrieved July $4^{\text {th }}, 2015$, from

www.simplypsychology.org/ questionnaires.html.

McLoed, S. A. (2018). Qestionnaire: definition. Example, design and types. Simply psychology.

Mohsen Tavakol and Reg Dennick

(2011). Making sense of Cronbach's Alpha.

International Journal of Medical Education.

Scott Thornbury. (2020) How to

teach vocabulary,

(Middlesex: Longman,

Pearson

Education. 
JELLT (Journal of English Language and Literature Teaching) Vol. 5 No. 02 November 2020

P.ISSN: 2548-7728 E.ISSN: 2599-0373 